\title{
Prevalence of Hydatidosis in Slaughtered Animals in Iran
}

\author{
Iran’ da Kasaplık Hayvanlarda Hidatidozun Yaygınlığı
}

\section{Mehdi Azami1', Mojtaba Anvarinejad', Behrouz Ezatpour², Masoud Alirezaei ${ }^{3}$}

${ }^{1}$ Professor Alborzi Clinical Microbiology Research Center, School of Medicine, Shiraz University of Medical Sciences, Shiraz, Iran ${ }^{2}$ Razi Herbal Medicines Research Center, lorestan University of Medical Sciences, Khorramabad, Iran

${ }^{3}$ Division of Biochemistry, School of Veterinary Medicine, lorestan University of Medical Sciences, Khorramabad, Iran

\begin{abstract}
Objective: Hydatid cyst or cystic echincoccosis (CE) is an important medical and veterinary problem in the world, especially in Iran. Domestic intermediate hosts are a major reservoir for the disease in humans. The aim of this study was to determine the prevalence of hydatid cysts in slaughtered animals in Isfahan, central part of Iran.

Methods: In this cross-sectional study performed from 10 May 2009 to 10 May 2010, a total of 196,325 animals (89,651 sheep, 93,050 goats, 9,112 cattle and 4,512 calves) were inspected macroscopically for hydatid cysts.

Results: Prevalence rate of CE in sheep, goats, cattle and calf was $16.4 \%, 3.1 \%, 6.5 \%$ and $8.2 \%$, respectively. In all cases, the prevalence in female cattle and sheep was more than in males $(P<0.001)$. There are significant seasonal pattern for hydatidosis only in sheep $(P<0.001)$ and the highest prevalence of cysts was seen in autumn and winter seasons. The fertility of cysts in the liver of sheep (77\%) was higher than in lungs (47.9\%), but was higher in lungs in cattle (44\%). Most condemnation cases were seen in lung of sheep (27.1\%).

Conclusion: It appears that sheep are the most important intermediate hosts for $E$. granolusus in this area.
\end{abstract} (Turkiye Parazitol Derg 2013; 37: 102-6)

Key Words: Hydatid cyst, slaughtered animals, prevalence

Received: 22.01.2013

Accepted: 30.04 .2013

\section{ÖZET}

Amaç: Hidatik kist veya kistik ekinokokkoz (KE) dünyada ve özellikle İran'da önemli bir medikal ve veterinerlik problemidir. Evcil ara konaklar insanlardaki hastalığın ana rezervuarıdır. Bu çalışmanın amacı İran'ın merkezi bölgesi olan İsfahan'da kesimlik hayvanlarda hidatik kist prevalansını belirlemekti.

Yöntemler: 10 Mayıs 2009 ile 10 Mayıs 2010 arasında yapılan bu kesitsel çalısmada toplam 196325 hayvan (89651 koyun, 93050 keçi, 9112 sığır ve 4512 buzağı) makroskopik olarak hidatik kist açısından incelendi.

Bulgular: Koyun, keçi, sığır ve buzağılardaki KE prevalans hızı sırasıyla \%16.4, \%3.1, \%6.5 ve \%8.2 idi. Tüm olgularda dişi sığır ve koyunlardaki prevalans erkeklerdekine göre daha yüksekti $(P<0.001)$. Hidatidoz için anlamlı mevsimsel patern sadece koyunlarda mevcuttu $(P<0.001)$ ve en yüksek kist prevalansı sonbahar ve kış mevsimlerinde görüldü. Kistlerin fertilitesi akciğerlere göre (\%47.9) koyun karaciğerinde (\%77) daha yüksekti ancak sığırların akciğerlerinde daha yüksekti (\%44). Hastalıklı vakaların çoğu koyunların akciğerinde görüldü (\%27.1).

Sonuç: Bu bölgede E. granulosus için en önemli ara konağın koyunlar olduğu görülmektedir. (Turkiye Parazitol Derg 2013; 37: 102-6)

Anahtar Sözcükler: Hidatik kist, kesimlik hayvanlar, prevalans

Geliş Tarihi: 22.01.2013

Kabul Tarihi: 30.04.2013

Address for Correspondence / Yazışma Adresi: Mojtaba Anvarinejad, Professor Alborzi Clinical Microbiology Research Center, Namazi Hospital, Shiraz University of Medical Sciences, Shiraz, Fars, Iran Phone: 0711-6474304 E-mail: anvarinejad@yahoo.com

doi:10.5152/tpd.2013.24 


\section{INTRODUCTION}

Inspection records of the slaughtered animals have been used as useful source for evaluation of the epidemiological aspect of certain disease in several countries (1-4). CE is a disease which causes considerable economic losses and public health problems. Hydatid cyst is the larval form of Echinococcus granulosus in intermediate hosts. CE or hydatidosis of livestock animals causes a decrease of their production such as meat, wool, and milk, and thereby high economic losses (3). Furthermore, the infected organs of the slaughtered animals are condemned. Because CE is a zoonotic disease, and is a matter of health, in many countries there are special programs to control and detect the disease (5). The reports have shown that the incidence of CE in animals in the Mediterranean and Middle East is high $(6,7)$. Based on the FAO report (8), infection with E. granulosus is common in all herbivorous animals in south west Asia. Also, there have been several reports from Middle Eastern countries including Iran which found sheep, cattle, goats, calf, buffaloes, and camels to be infected with hydatid cysts (9-12). To the best of our knowledge, there are limited studies about the prevalence of CE in slaughtered animals in Isfahan, Iran. Therefore, this study was undertaken to estimate the prevalence of CE in slaughtered animals in Isfahan, Iran. The site, intensity and fertility of cysts as well as viability of their protoscolices were also determined.

\section{METHODS}

This cross-sectional study was carried out on 196,325 animals (89,651 sheep, 93,050 goats, 9,112 cattle and 4,512 calves) in three the large animal slaughterhouses in Isfahan, Iran, between 10 May 2009 and 10 May 2010. During the study, the slaughterhouse was visited daily for 1 year to examine the internal organs (liver and lungs) for the presence of cystic echinococcosis. A questionnaire about the type of animal, gender, infected organ and number of cysts was completed for every animal. To determine the intensity of infection, the number of cysts was counted. Intensity of infection was divided into two categories: light infection ( $1-10$ cysts) and intense infection (more than 10 cysts). The rate of total condemnation in different animals was calculated.

Animal cysts were grossly examined for degeneration and calcification. Then, according to the size and form of cysts as well as infected organs, $5 \%$ of hydatid cysts in sheep and all of cattle cysts were randomly selected for fertility studies. The surface of each cyst was sterilised with alcoholic iodine solution. To reduce intracystic pressure, the cyst wall was penetrated, using a large size needle and a cut made with a scalpel and scissors, before the contents were transferred into a sterile container. The contents were examined under a microscope (40x) for the presence of protoscolices into the cyst. The cysts which contained no protoscolex as well as calcified cysts were considered unfertile cysts.

The viability of the protoscolices was assessed by motility of flame cells as well as ease of staining with $0.1 \%$ aqueous eosin solution and examination under a light microscope (13). Lived protoscolices did not take up the dye, whereas the dead ones did. Data were analysed using SPSS 16 software and to determine the different between distribution of infection rate and season, gender, site of cyst, fertility rate of cyst and means of viability of protoscolices, data were analysed using Chi-square and student t-test, respectively.

\section{RESULTS}

During the study, the internal organs (liver and lungs) of 196,325 indigenous slaughtered sheep $(n=89,651)$, goats $(n=93,050)$, cattle $(n=9,112)$ and calves $(n=4,512)$ were examined for the presence of cysts. The highest prevalence of infection was found in sheep (16.4\%) and the lowest was seen in goats (3.1\%). The frequency distribution of CE in different animals is shown in Table 1. The infection rate in female cattle and sheep was higher than in males $(p<0.001)$.

While cysts in cattle, calves and sheep were found mostly in the lungs (43.4, 38.7 and 50.2, respectively), CE were more common in the liver than in the lungs of goats. Co-infection of the liver and lungs was common in calves. The majority of the cattle, calves, sheep and goats had 1-10 cysts in the lungs and liver. In all animals, heavy infection (>10 cysts) in the lungs was higher than liver. The highest and lowest total offal condemnation was seen in the lungs of sheep (27.1\%) and liver of goats (11.6\%), respectively (Table 2 ).

Data showed a significant seasonal pattern for hydatidosis only in sheep $(p<0.001)$ and the highest prevalence rate of CE in sheep was seen in autumn and winter seasons (Table 3).

The fertility rate of cyst in lungs or liver of sheep and cattle are shown in Table 4. The cysts obtained from the liver and lungs of sheep showed more fertility than those of cattle $(p<0.05)$.

\section{DISCUSSION}

Hydatidosis causes considerable economic loss in livestock due to the condemnation of organs. Therefore, it is justifiable to find reliable data for monitoring epidemiologic aspects of disease and prepare baseline data for future comparison. Although abattoir surveys have limitations, they are an economic way of gathering information on livestock disease. It is suggested that an efficient

Table 1. Prevalence rate of cystic echincoccosis in male and female animals slaughtered in Isfahan, 2009-2010

\begin{tabular}{|c|c|c|c|c|c|}
\hline \multirow[t]{2}{*}{ Animals } & \multicolumn{2}{|c|}{$\begin{array}{c}\text { Number of animals } \\
\text { examined }\end{array}$} & \multicolumn{2}{|c|}{$\begin{array}{c}\text { Number of infected } \\
\text { animals (\%) }\end{array}$} & \multirow[t]{2}{*}{$\begin{array}{c}\text { Total number of } \\
\text { Infected animals (\%) }\end{array}$} \\
\hline & Male & Female & Male & Female & \\
\hline Sheep & 39754 & 49897 & 5751 (14.5\%) & 8931 (17.9\%) & $14682(16.4 \%)$ \\
\hline Goats & 38189 & 54861 & 1101 (2.9\%) & 1695 (3.1\%) & 2796 (3.1\%) \\
\hline Cattle & 3975 & 5137 & $123(3.1 \%)$ & 463 (9.1\%) & $586(6.5 \%)$ \\
\hline Calf & 4102 & 410 & $123(3.1 \%)$ & $463(9.1 \%)$ & 368 (8.2\%) \\
\hline
\end{tabular}


Table 2. Prevalence, intensity and offal condemnation rate of cystic echincoccosis in different organs from slaughtered animals in Isfahan, 2009-2010

\begin{tabular}{|c|c|c|c|c|c|c|c|c|c|c|c|c|c|c|}
\hline \multirow{3}{*}{$\begin{array}{l}\text { Animals } \\
\text { (No.) }\end{array}$} & \multicolumn{4}{|c|}{ Liver } & \multicolumn{4}{|c|}{ Lungs } & \multirow{2}{*}{\multicolumn{2}{|c|}{$\begin{array}{l}\text { Co-infection of } \\
\text { livers and lungs }\end{array}$}} & \multicolumn{4}{|c|}{ Condemnation } \\
\hline & \multicolumn{2}{|c|}{$<10$ cysts } & \multicolumn{2}{|c|}{$>10$ cysts } & \multicolumn{2}{|c|}{$<10$ cysts } & \multicolumn{2}{|c|}{$>10$ cysts } & & & \multicolumn{2}{|c|}{ Liver } & \multicolumn{2}{|c|}{ Lungs } \\
\hline & No. & $\%$ & No. & $\%$ & No. & $\%$ & No. & $\%$ & No. & $\%$ & No. & $\%$ & No. & $\%$ \\
\hline Sheep & 3925 & 26.8 & 1944 & 13.3 & 5499 & 37.5 & 1862 & 12.7 & 1452 & 9.9 & 2181 & 14.9 & 3967 & 27.1 \\
\hline Goats & 788 & 28.2 & 631 & 22.6 & 520 & 18.6 & 418 & 15 & 439 & 15.8 & 324 & 11.6 & 451 & 16.2 \\
\hline Cattle & 123 & 20.9 & 93 & 15.9 & 171 & 29.2 & 83 & 14.2 & 116 & 19.8 & 143 & 24.5 & 108 & 18.5 \\
\hline Calf & 68 & 18.5 & 63 & 17.2 & 100 & 27.2 & 42 & 11.5 & 95 & 25.9 & 89 & 24.2 & 96 & 26.1 \\
\hline
\end{tabular}

Table 3. Seasonal prevalence rate of cystic echincoccosis in animals slaughtered in Isfahan, 2009-2010.

\begin{tabular}{|l|c|c|c|c|c|c|c|c|}
\hline \multirow{2}{*}{ Animals } & \multicolumn{2}{|c|}{ Spring } & \multicolumn{2}{c|}{ Summer } & \multicolumn{2}{c|}{ Autumn } & \multicolumn{2}{c|}{ Winter } \\
\cline { 2 - 9 } & Ex. Animals & Inf. Animals (\%) & Ex. animals & Inf. Animals (\%) & Ex. animals & Inf. Animals (\%) & Ex. animals & Inf. Animals (\%) \\
\hline Sheep & 20420 & $2749(13.5)$ & 21306 & $2987(14.1)$ & 23543 & $4793(20.1)$ & 24382 & $4153(17.1)$ \\
\hline Goats & 22082 & $445(2.1)$ & 22201 & $355(1.6)$ & 24961 & $1001(4.1)$ & 23806 & $995(4.2)$ \\
\hline Cattle & 2371 & $183(7.8)$ & 2421 & $155(6.5)$ & 2169 & $150(6.9)$ & 2151 & $98(4.6)$ \\
\hline Calf & 938 & $106(11.4)$ & 1299 & $95(7.4)$ & 1034 & $88(8.6)$ & 1241 & $79(6.4)$ \\
\hline
\end{tabular}

Table 4. Fertility of cystic echincoccosis and viability of protoscolices of fertile cysts recovered from different organs animals in Isfahan, 2009-2010

\begin{tabular}{|l|c|c|c|c|c|c|c|}
\hline \multirow{2}{*}{ Animals } & \multirow{2}{*}{$\begin{array}{c}\text { Infected } \\
\text { organs } \\
\text { examined }\end{array}$} & \multirow{2}{*}{$\begin{array}{c}\text { No. of cysts } \\
\text { examined }\end{array}$} & \multicolumn{2}{|c|}{ Sterile cysts } & \multicolumn{2}{|c|}{ Fertility cysts } & \multirow{2}{*}{$\begin{array}{c}\text { Viability of } \\
\text { protoscolices in } \\
\text { fertile cysts (mean } \pm \text { SD) }\end{array}$} \\
\cline { 4 - 8 } & Liver & 400 & No. & $\%$ & No. & $\%$ & $62.28 \pm 31.04$ \\
\hline \multirow{2}{*}{ Sheep } & Lungs & 334 & 174 & 52.1 & 160 & 47.9 & $64.91 \pm 30.84$ \\
\cline { 2 - 8 } & Liver & 300 & 201 & 67 & 99 & 33 & $35.67 \pm 22.98$ \\
\cline { 2 - 7 } & Lungs & 286 & 160 & 56 & 126 & 44 & $34.20 \pm 20.61$ \\
\hline
\end{tabular}

meat inspection service should function as an important monitor of animal disease, being particularly valuable in the field of chronic and ill-defined conditions which are not apparent to either the stockowner or his veterinary surgeon, but which must be of considerable economic and animal health significance (14). Also, a feedback from the slaughterhouse to the individual farm is of great value in the field of preventive medicine.

In the present study, the prevalence of hydatid disease in the region (Table 1) was relatively lower than reports from neighbouring countries in the Middle East such as Iraq (10), Jordan (11) and Syria (12). From Iran, based on abattoir surveys, the mean prevalence of hydatidosis of sheep in different parts of the country has been reported to be $8.1 \%$ and corresponding features for cattle and goats were 12 and 6.5\%, respectively (9). The highest prevalence of the disease was seen in sheep and then in cattle (15).

One reason for the high prevalence of hydatidosis in sheep is that sentinel dogs often live close to sheep flocks since they are used as sheep guards. In contrast, cattle are mostly bred in modern farms with no dogs. This may explain a lesser prevalence of the infection in cattle. The lowest prevalence of hydatidosis in goats is probably due to the diet of goats. Goats naturally tend to graze on leaves and tall bushes in hilly or mountainous areas; this grazing style results in less contact with infective eggs and hence a lower risk of infection in goats compared to cattle and sheep (2).

In the current study, the prevalence of CE in lungs was higher than that in livers in all animal species. Many studies have evaluated the prevalence of CE in livers or lungs of livestock. Eslami et al. (15) found that the infection was mostly in the lungs in sheep. In contrast, the infection was spread predominantly in the livers in cattle. In pigs, infection was spread equally in lungs and in livers. In a five-year survey by Ansari-Lari (2) in Shiraz (Southern Iran), the condemnation of lungs in cattle, sheep and goats (2\%, $2.5 \%$ and $1.5 \%$, respectively) was higher than the condemnation of livers in those animals (1.3\%, $1.3 \%$ and $0.4 \%$, respectively). In a study in Kashan (Central Iran), Arbabi and Hooshyar (16) found that the rate of lung infection in sheep and goats $(2.8 \%$ and $3.9 \%$, respectively) was higher than the rate of liver infection in those animals (1.7\% and $2.3 \%$, respectively). In cattle, in contrast, the infection rate in livers was higher than that in lungs $(4.4 \%$ instead of $3.7 \%$ ). In a five-year study in 28 Iranian provinces, the average rate of infection in lungs in cattle, sheep and goats was 1.8 times greater than that in livers in those animals (17). 
However, because of the high affinity of the parasite to infect lungs and due to a lower price, lungs were condemned more often than livers.

Data on the prevalence and fertility of cysts in various domestic herbivores provide reliable indicators of the importance of each type of animals as a potential source of infection to dogs. Cysts depending on geographical situation, kind of infected hosts, site, size and type of cyst may have different fertility rates. In this study, the fertility rates of hepatic cyst of sheep and cattle were $77 \%$ and $33 \%$, respectively, and the fertility rates of pulmonary cyst of sheep and cattle were $47.9 \%$ and $44 \%$, respectively. In sheep, the fertility of cysts in the liver was higher than in lungs and in the cattle the fertility of cysts in the lung was higher than in liver. The results of Dalimi et al. (9) are similar to those of our study. Gusbi et al. (18) reported that the liver cysts of Libyan sheep were more likely to be fertile than the lung cysts.

The viability of protoscolices of fertile cysts for sheep and cattle were about 63\% and 32\%, respectively. Dalimi et al. (9) in western Iran reported that the viability in sheep (82\%) was higher than in cattle (75\%). Yıldız and Tunçer (19) have found the fertile cyst rate to be $6.6 \%$ in Kırıkkale, Turkey. Dalimi et al. (9) reported this as $10.2 \%$ in Western Iran, whereas Saeed et al. (20) found the fertility rate to be $29.8 \%$ in Northern Iraq. The rate of fertile cysts may indicate that the cause of infections in cattle might be due to the sheep strain as it is known that its lifecycle is almost exclusively domestic, involving dogs as definitive and (predominantly) sheep as intermediate hosts (21). However, further molecular studies are necessary to confirm the cause of CE in cattle in this region to reach the final conclusion.

Most animals slaughtered for human consumption in abattoirs in this area are sheep, followed by goats, cattle and calves. Furthermore, since $63.8 \%$ of sheep were fertile, it appears that sheep are a potential source of infection to dogs. This is because the offal from these animals (especially the livers and lungs) is usually offered to domestic dogs or is dumped in rubbish bins outside houses where stray dogs may easily feed on it. However, only $38.4 \%$ of cattle cysts were fertile and most of them are sterile and degenerate, so these animals would not be source of infection to dogs.

Based on the distribution of CE in different seasons, only sheep showed a significant variation $(P<0.001)$. The highest prevalence of hydatidosis was observed in the autumn and winter. The sources of slaughtered animals might be an epidemiological reason of this finding, as a greater portion of the sheep slaughtered near the end of autumn and in the early of winter usually belong to tribal people. It is reported that the prevalence of hydatidosis is relatively higher in animals belonging to this group (22). During spring and summer, the sheep are moved to the mountains in the suburb of Isfahan and in the middle of autumn are returned to the city. In this time, shepherds, send old sheep to the abattoir, because these animals are usually thinner and less efficient and probably infected with CE. Therefore, CE accumulation in autumn and winter is higher than other seasons. Of course, this migration situation does not exist in training cattle, calves and goats; usually, these animals are kept in houses and stables. In a study by AnsariLari (2) in Fars Province, significant seasonal effects on the con- demnation of livers and lungs were evaluated. The highest prevalence rate of the infection in livers and lungs was found in the spring and summer and in the summer, respectively.

\section{CONCLUSION}

This study has evaluated the prevalence of hydatidosis in slaughtered livestock in the centre of Iran from 2009 to 2010. Although data collected from slaughterhouses may not be highly accurate due to technical problems, the direct inspection method still seems to be the best approach to estimate the prevalence of hydatidosis in livestock. In general, data from the current study show a little decrease in the prevalence of hydatidosis. Therefore, more action is suggested to control the disease in Iran. To reach this goal, stronger monitoring of the slaughtering process is highly recommended as well as the treatment of stray dogs. Also, data showed that intensity and fertility of CE in sheep is higher than other animals, so it appears that sheep have a more important role in the continuation of the E. granulosus life cycle in this region. Therefore, effort should be made to control the transmission of cysts from slaughter houses by the safe disposal of infected offal.

\section{Conflict of Interest}

No conflict of interest was declared by the authors.

Peer-review: Externally peer-reviewed.

\section{Author Contributions}

Concept - M.AZ.; Design - M.AZ., B.E.; Supervision - M.AZ., B.E.; Funding - M.AZ., M.AL.; Materials - M.AZ., B.E.; Data Collection and/or Processing - M.AZ., B.E.; Analysis and/or Interpretation M.AN., B.E., M.AL.; Literature Review - M.AZ., M.AN.; Writing M.AN.; Critical Review - M.AZ., B.E., M.AL.

\section{Acknowledgements}

The assistance of the meat inspection and abattoir staffs, especially Dr Ali Jafari, in collecting the data for this study is greatly appreciated.

\section{Çıkar Çatışması}

Yazarlar herhangi bir çıkar çatışması bildirmemişlerdir.

Hakem değerlendirmesi: Dış bağımsız.

\section{Yazar Katkıları}

Fikir - M.AZ.; Tasarım - M.AZ., B.E.; Denetleme - M.AZ., B.E.; Kaynaklar - M.AZ., M.AL.; Malzemeler-M.AZ., B.E.; Veri toplanması ve/veya işlemesi - M.AZ., B.E.; Analiz ve/veya yorum - M.AN., B.E., M.AL.; Literatür taraması - M.AZ., M.AN.; Yazıyı yazan - M.AN.; Eleştirel Inceleme - M.AZ., B.E., M.AL.

\section{Teşekkür}

Yazarlar, mezbaha ve et denetleme personeline, özellikle Dr. Ali Jafari'ye veri toplama aşamasındaki yardımlarından dolayı teşekkür ederler.

\section{REFERENCES}

1. Kara M, Gicik Y, Sari B, Bulut H, Arslan M. A slaughterhouse study on prevalence of some helminths of cattle and sheep in Malatya province, Turkey. J Anim Vet Adv 2009; 8: 2200-5. 
2. Ansari-Lari M. A retrospective survey of hydatidosis in livestock in Shiraz, Iran, based on abattoir data during 1999-2004. Vet parasitol 2005; 133: 119-23. [CrossRef]

3. Umur S. Prevalence and economic importance of cystic echinococcosis in slaughtered ruminants in Burdur, Turkey. J Vet Med Ser B 2003; 50: 247-52. [CrossRef]

4. Mirani A, Akthar N, Brohe M, Bughio S, Oad F. Hydatidosis in buffaloes at Larkana slaughter house (Pakistan). Pakistan J Biol Sci 2000; 3: 1311-12. [CrossRef]

5. Oku Y, Malgor R, Benavidez U, Carmona C, Kamiya H, editors. Control program against hydatidosis and the decreased prevalence in Uruguay. Int Congr Ser 2004; 1267: 98-104.

6. Sadjjadi SM. Present situation of echinococcosis in the Middle East and Arabic North Africa. Parasitol Int 2006; 55: 197-202. [CrossRef]

7. Battelli G, Mantovani A, Seimenis A. Cystic echinococcosis and the Mediterranean Region: a long-lasting association. Parassitol 2002; 44: 43-57.

8. Over HJ, Jansen J, Van Olm P. Distribution and impact of helminth diseases of livestock in developing countries. Rome: Food \& Agriculture Org; 1992, Paper 96.

9. Dalimi A, Motamedi G, Hosseini M, Mohammadian B, Malaki H, Ghamari Z, et al. Echinococcosis/hydatidosis in western Iran. Vet Parasitol 2002; 105: 161-71. [CrossRef]

10. Molan AL. Epidemiology of hydatidosis and echinococcosis in Theqar Province, southern Iraq. Jpn J Med Sci Biol 1993; 46: 29-35.

11. Abo-Shehada MN. Some observations on hydatidosis in Jordan. J Helminthol 1993; 67: 248-52. [CrossRef]

12. Dajani Y. Prevalence of hydatid disease in Syria and Jordan: preliminary results. Trans Roy Soc Trop Med Hyg 1978; 72: 320-1. [CrossRef]
13. Smyth J, Barrett N. Procedures for testing the viability of human hydatid cysts following surgical removal, especially after chemotherapy. Trans Roy Soc Trop Med Hyg 1980; 74: 649-52. [CrossRef]

14. Blamire R, Goodhand R, Taylor K. A review of some animal diseases encountered at meat inspections in England and Wales, 1969 to 1978. Vet Rec 1980; 106: 195-9. [CrossRef]

15. Eslami, A, Rahbari S, Meydani M. Cestodes and trematodes of wild sheep, Ovis ammon orientalis, and goitered gazelle, Gazella subgutturosa, in Iran. Vet Parasitol 1981; 8: 99-101. [CrossRef]

16. Arbabi $\mathrm{M}, \mathrm{Hooshyar} \mathrm{H}$. Survey of echinococcosis and hydatidosis in Kashan Region, Central Iran. Iran J Pub Healt 2006; 35: 75-81.

17. Tavakoli H, Bayat M, Kousha A. Hydatidosis Infection Study in Human and Livestock Populations During 2002-2007. Am-Eurasian J Agri Environ Sci 2008; 4: 473-7.

18. Gusbi AM, Awan MA, Beesley WN. Echinococcosis in Lybia. II. Prevalence of hydatidosis (Echinococcus granulosus) in sheep. Ann Trop Med Parasitol 1987; 81: 35-41.

19. Yıldız K, Tunçer Ç. Kırıkkale'de sığırlarda kist hidatik'in yayılışı. Türkiye Parazitol Derg 2005; 29: 247-50.

20. Saeed I, Kapel C, Saida LA, Willingham L, Nansen P. Epidemiology of Echinococcus granulosus in Arbil province, northern Iraq, 19901998. J Helminthol 2000; 74: 83-8.

21. Romig T, Dinkel A, Mackenstedt $U$. The present situation of echinococcosis in Europe. Parasitol Int 2006; 55: 187-91. [CrossRef]

22. Hoghoughi N. A study of the prevalence of Echinococcus granulosus in dogs and hydatid cyst in sheep, goats, cattle and Man in Isfahan. Pahla Med J 1971; 2: 670-6. 